Premiere Educandum: Jurnal Pendidikan Dasar dan Pembelajaran

Volume 10 (1) 112 - 124 Juni 2020

ISSN: 2088-5350 (Print) / ISSN: 2528-5173 (Online)

Doi: $10.25273 /$ pe.v10i1.6344

The article is published with Open Access at: http://e-journal.unipma.ac.id/index.php/PE

\title{
Use of instagram to improve verbal-linguistic intelligence and kinesthetic-body intelligence of low-class students through scientific approach in primary schools
}

Aan Yuliyanto $\bowtie$, Universitas Pendidikan Indonesia

Dinda Mifta Amalia, Laboratory of Elementary Schools of the Universitas Pendidikan Indonesia Idat Muqodas, Universitas Pendidikan Indonesia

$\triangle$ aanyuliyanto@upi.edu

Abstract: Verbal-Linguistic Intelligence and Kinesthetic-Body Intelligence are important for students to have at an early age. The purpose of this study is to see improvement in VerbalLinguistic and Kinesthetic-Body Intelligence through Instagram-assisted Scientific Approaches. The study used a pre-experimental method with one group pretest-posttest design on the thematic learning of my hobby topic. Determination of the sample by purposive sampling technique. Participants consisted of 15 male students and 12 female students in first-grade elementary school in Purwakarta Regency. Measurement through observation and documentation to observe and record the activities of students' verbal-linguistic and kinesthetic intelligence. Research shows an increase in Verbal-Linguistic and Kinesthetic-Body Intelligence is in the medium category with ngain values of 0.59 and 0.56 , and an increase in Verbal-Linguistic and Kinesthetic-Body Intelligence after learning with a more scientific-assisted Instagram approach significantly better than before being treated with sig. $0,000<0.05$. The use of Instagram shows students enthusiastic about expressing their hobbies. Learning development should be able to accommodate a variety of student intelligence and utilize social media that serves to facilitate learning and assessment more interesting.

Keywords: Verbal-Linguistic Intelligence, Kinesthetic-Body Intelligence, Scientific Approach, Instagram

Abstrak: Kecerdasan Verbal-Linguistik dan Kecerdasan Kinestetik-Tubuh penting dimiliki siswa sejak dini. Tujuan studi ini untuk melihat peningkatan Kecerdasan Verbal-Linguistik dan Kinestetik-Tubuh melalui Pendekatan Saintifik berbantuan Instagram. Studi menggunakan metode pre-experimental dengan one group pretest-posttest design pada pembelajaran tematik topik hobiku. Penentuan sampel dengan teknik purposive sampling. Peserta terdiri 15 siswa laki laki dan 12 siswa perempuan pada kelas satu SD di Purwakarta. Pengukuran melalui observasi dan dokumentasi untuk mengamati dan merekam aktivitas kecerdasan verbal-linguistik dan kinestetiktubuh siswa. Studi menunjukkan peningkatan Kecerdasan Verbal-Linguistik dan Kinestetik-Tubuh berada pada kategori sedang dengan nilai n-gain berturut-turut 0,59 dan 0,56, serta peningkatan Kecerdasan Verbal-Linguistik dan Kinestetik-Tubuh setelah diberi pembelajaran dengan pendekatan saintifik berbantuan Instagram lebih baik secara signifikan dibanding sebelum diberi perlakuan dengan nilai sig. 0,000<0,05. Penggunaan Instagram menunjukkan siswa antusias mengekspresikan hobinya. Pengembangan pembelajaran seharusnya dapat mewadahi kecerdasan siswa yang bervariasi dan memanfaatkan media sosial yang berfungsi memudahkan pembelajaran dan penilaian lebih menarik.

Kata kunci: Kecerdasan Verbal-Linguistik, Kecerdasan Kinestetik-Tubuh, Pendekatan Saintifik, Instagram

Received 28 April 2020; Accepted 05 May 2020; Published 01 June 2020 
Citation: Yuliyanto, A., Amalia, D. M., \& Muqodas, I. (2020). Use of instagram to improve verballinguistic intelligence and kinesthetic-body intelligence of low-class students through scientific approach in primary schools. Premiere Educandum: Jurnal Pendidikan Dasar dan Pembelajaran, 10(1), 112 - 124. Doi.org/10.25273/pe.v10i1.6344

\section{(cc) EY-NC-SA}

Copyright (C2020 Premiere Educandum : Jurnal Pendidikan Dasar dan Pembelajaran

Published by Universitas PGRI Madiun. This work is licensed under the Creative Commons Attribution-NonCommercialShareAlike 4.0 International License. 


\section{INTRODUCTION}

All students are expected to develop their intelligence early on, according to what has mandated in the National Education System Law that education is a conscious and planned effort to create an atmosphere of learning and learning process so that students actively develop their intelligence (UU No 20 Tahun 2003, 2003). One of the functions of education is to develop the intelligence potential of students. Student intelligence has many types, including based on research has found nine intelligences called multiple intelligences. Multiple intelligences are proven to help realize diverse educational goals, one of which is the development of multidisciplinary learning and assessment (Gardner, 1993). In this study will reveal verbal-linguistic and kinesthetic-body intelligence. The selection of these two bits of intelligences is because verbal-linguistic intelligence plays a role in developing the language skills of low-grade students, and kinesthetic-body intelligence is very prominent in low-grade students, this is seen in the hyperactivity of these low-grade students. Linguistic intelligence is the ability to use words effectively. This intelligence includes the ability to manipulate the structure of language, phonology or language sounds, semantic, or meaning of language, and the practical use of language (Armstrong, 2009). One study said verbal-linguistic intelligence must certainly be prepared and chosen as effectively as possible to facilitate the category of early childhood to obtain this intelligence (Setyorini, Saddhono, Ermanto, Wildan, \& Kirom, 2019). Besides, verballinguistic intelligence in children can show the extent to which the ability to think logically. So, a child who is intelligent in linguistics can speak well and effectively (Hanifah, 2014). People who have linguistic intelligence can easily influence others. The style of language, speech, verbal motion, the right expression when talking, all have extraordinary allure (Nining, 2018). Whereas if we have well-developed bodily-kinesthetic intelligence, we can manage body movements and physical experience of touch with the main activity of coordinating body movements to express ideas, feelings and shape things (Laduni, Novianti, \& Febrialismanto, 2016). Besides kinesthetic intelligence as a method for reducing academic stress (Roberts, 2010). The description suggests that verbal-linguistic and kinesthetic-body intelligence is important for students.

Behind the importance of verbal-linguistic and kinesthetic-body intelligence, the fact is that the intelligence is still low and learning has not been done to facilitate this intelligence. A study found that the results of students' linguistic tests showed that the majority of students had linguistic intelligence insufficient categories, as many as 20 students. The other abilities are good categories as many as 14 students, and fewer categories are as many as 10 students (Riana, Monawati, \& Hasan, 2017). Also found a study said the average kinesthetic intelligence of students is still in the category began to develop (Putri, Yuwono, \& Utami, 2018).

Based on the description, the problem of verbal-linguistic and kinesthetic-body intelligence is still low. The need for more efforts to develop this intelligence. Learning following students' linguistic intelligence, including methods of demonstration, observation, discussion, question and answer, and role-playing (Bustamam, Trinova, \& Febrianto, 2016). Besides learning that is used to develop each linguistic intelligence is reading, writing, discussing, listening to information about the matter in question and for kinesthetic-physical is wake up, demonstrate, touch, pull the thing concerned (Katni, 2015). The scientific approach is considered to be able to develop verbal-linguistic and kinesthetic-body intelligence. A scientific approach is an approach using scientific process skills that allows students to be active in the learning process by finding, identifying, building their learning with the teacher as a facilitator, without explaining the material by the teacher directly (Yuliyanto, Fadriyah, Yeli, \& Wulandari, 2018). The scientific approach has also been used in the curriculum in Indonesia. The term learning by doing is learning that essentially teaches students through activity, so students play an active role in the learning process (Wakhidah, 2018). A scientific approach is a collection of techniques for 
investigating phenomena, gaining new knowledge, or correcting and integrating prior knowledge. (Hasanah, 2016). The essence of a scientific approach is a scientific approach that gives allows students to take an active role and expressing their abilities. The steps of the scientific approach include students being asked to observe the media, the teacher encourages students to ask questions, encourages students to dig up information, guides students to try the media, does the discussion exercises, conveys the results of the discussion (Rusnah \& Mulya, 2018). The scientific approach makes it easy for teachers to improve the learning process, namely by breaking down the process into detailed stages that contain instructions for students carrying out learning activities (Yustitia, Rusminati, \& Sulistyawati, 2018). The scientific approach stage consists of 5 stages namely observing, teachers open up opportunities widely for students to ask questions, carried out to explore information, an activity to process information, and provide opportunities for students to communicate what they have learned (Machin, 2014). The Scientific approach steps include observing the attention to the teacher conveying, asking questions with the others, trying to find information about a concept, analyzing the concepts being studied, and conveying the findings. Intelligent verbal-linguistic students can develop their language through the process of observing the object being studied, reasoning what has been obtained from the process of developing their speaking ability in the communication process. Children who are kinesthetic smart body will enjoy the process of trying and doing activity-based learning, the process of observing and touching the object being studied will develop motoric kinesthetic. Learning activities in a scientific approach are done hands-on activity and can be done inside and outside the classroom, especially in the process of observation, and try to do what they have learned. In line with this, linguistic intelligence can be stimulated through activities carried out outside the classroom by carrying out a variety of activities including those that can develop all aspects of intelligence development in cooperative activities designed through play activities (Purwaningsih, 2014). The scientific approach involves students in learning activities that require HOT'S, and in multiple intelligences, many intelligence indicators that include conclusions based on experimental results, make hypotheses, predict, analyze, identify, and explain (Dewi \& Rukmini, 2019). A scientific approach is also needed to develop student body functions (Kim, 2019). Learning using a scientific approach can refer to multiple intelligence theories so that at this stage, the teacher can determine the intelligence that will be facilitated in the lesson. The teacher's learning plan and worksheets are also followed by students' hypotheses of thought and teacher's alternative responses to every possibility so that the teacher can overcome the difficulties students face during the learning process (Kusrini \& Rizkianto, 2017). Based on the previous description, the scientific approach is considered to be able to develop the verballinguistic and kinesthetic intelligence of the body.

Learning with a scientific approach in developing verbal-linguistic and kinestheticbody intelligence can utilize Instagram social media in exploring learning. Social media allows its users to share and network more flexibly without having to be in the same place and time. The use of social media in learning provides more opportunities for students to exchange information with other students through various activities (Hanoum, 2014). Instagram can provide influence and benefits to the world of education, especially in the learning process, students can add knowledge and also information that can stimulate their creativity while also being useful to publish the results of their creativity, for example by uploading photos or videos of their creativity (Rubiyati, Asrori, \& Wicaksono, 2018). Instagram as a tool that can record videos or photos of students. It's the most valuable learning tools in each class. Recorders offer students a medium that is used to learn about their linguistic power and help develop verbal skills to communicate and express inner feelings. Students can use recorders to speak aloud about projects they plan to do, making videos can record and explore activity-based learning that is considered suitable for kinesthetic smart students (Armstrong, 2009). A study indicates that students tend to have positive perceptions of the use of Instagram in speaking class. Furthermore, there 
was an improvement in students' speaking skills after been taught by using Instagram (R \& Seftika, 2019). Using Instagram can be an innovative media as it is used by students and teachers for educational aims appropriately (Basith \& Syafi'i, 2019). Instagram in this study is used to explore student learning activities in expressing their language and kinesthetic skills related to their hobbies. Based on the description, this study will reveal an increase in verbal-linguistic and kinesthetic-body intelligence of low-grade elementary school students through an Instagram-assisted scientific approach.

\section{METHOD}

\section{Research Method}

The study applied a pre-experimental method with one group pretest-posttest design. Preexperimental does an excellent job of controlling foreign variables that jeopardize the validity of one group. One group pretest-posttest design involves one group that is pretest $(0)$, exposed to treatment $(\mathrm{X})$, and then tested again (O). The success of the treatment is determined by comparing the pretest and posttest scores (Gay, Milss, \& Airasian, 2012).

\section{Participant}

The study population was first-grade students in elementary schools in Purwakarta Regency. The sample in this study involved 27 students. The technique of determining the sample using purposive sampling method, the sampling technique considers several things (Patton, 2015).

\section{Materials}

The research instrument used observation sheets to measure the verbal-linguistic and kinesthetic-body intelligence of students and documentation. Based on the validity and reliability test of the observation instrument, all statements with high validity $\left(r_{\mathrm{xy}}=0.81\right)$ and very high reliability $\left(r_{11}=0.90\right)$. Indicators used in the measurement of verballinguistic intelligence are listening and responding to sound, rhythmic, color and variation in the pronunciation of words, understanding sound, language, reading, and writing, others learn through listening, reading, writing and discussing, being able to speak, read, hear, and write effectively, experience in learning other people's languages using hearing, speaking, writing, and reading to communicate trying hard to improve the use of their language, paying attention to journalistic demonstrations, poetry and so on creating new and original forms of linguistics from spoken and spoken languages. writing. While the body's kinesthetic intelligence is used the following indicators can explore the environment and objects through touch and movement able to develop coordination and meaning of time, able to enjoy concrete learning through experience, showing dexterity in working with motor motion, responsive to systems and physical environment able to demonstrate capable motor movements, demonstrating balance movements, supremacy, graceful physical movements, understanding life with healthy physical standards undergoing a career as an athlete or dancer creating a new physical skill approach to dance, sports movements or other physical activities.

\section{Procedures}

This research was conducted by giving preliminary observations before giving treatment with an Instagram-assisted scientific approach. Furthermore, students were given a scientific approach to the treatment of my hobby material, students were assigned to tell and show their hobbies through Instagram media, students were free to tell their hobbies 
in Sundanese, Indonesian and English. After that, the students observed their verballinguistic and bodily-kinesthetic intelligence.

\section{Data Analysis}

Data analysis was performed by identifying the increase in student intelligence by calculating the student's n-gain, then the data were analyzed descriptively and inferentially. Data analysis using the average difference test using the Mann Whitney U test with the help of SPSS 25 for macOS.

\section{RESULTS}

Increased verbal-linguistic and kinesthetic-body intelligence seen from Normalized Gain. The improvement criteria are grouped based on the criteria stated by (Meltzer, 2002) as follows.

TABLE 1. Criteria for increasing student's multiple intelligences

\begin{tabular}{cc}
\hline Increase Interval & Improvement Criteria \\
\hline $\mathrm{N}-$ Gain $>0.7$ & High \\
$0.3<\mathrm{N}$-Gain $\leq 0.7$ & Medium \\
$\mathrm{N}-$ Gain $\leq 0.3$ & Low \\
\hline
\end{tabular}

\section{Verbal-Linguistic Intelligence Descriptive Analysis}

Recapitulation of the initial and final score results of verbal-linguistic intelligence and normalized Gain based on learning can be seen in Table 2 .

TABLE 2. Recapitulation of student's verbal-linguistic intelligence enhancement

\begin{tabular}{|c|c|c|c|c|c|c|}
\hline \multirow{2}{*}{ Score } & \multirow{2}{*}{ Learning } & \multicolumn{2}{|c|}{ Score } & \multirow{2}{*}{$\bar{x}$} & \multirow{2}{*}{$S d$} & \multirow{2}{*}{ N-Gain } \\
\hline & & Min & Max & & & \\
\hline Pre-VLI & \multirow{2}{*}{ Scientific \& IG } & 6 & 15 & 10.74 & 2.93 & \multirow{2}{*}{0,59} \\
\hline Post-VLI & & 9 & 20 & 16.19 & 2.92 & \\
\hline
\end{tabular}

Based on Table 2, it appears that the verbal-linguistic intelligence of students with Instagram-assisted scientific learning treatment has increased. Qualification improvement is in the medium criteria. The following are the complete enhancements to the following Figure 1.

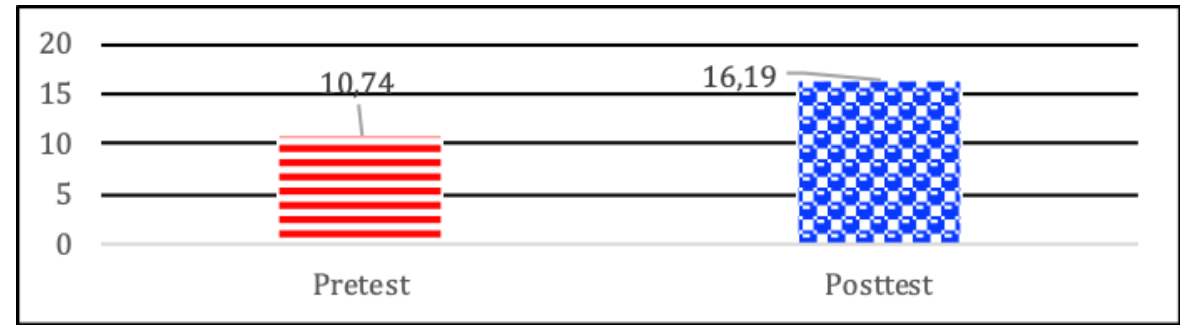

FIGURE 1. Average increased verbal-linguistic intelligence

\section{Verbal-Linguistic Intelligence Inferential Analysis}

Descriptive it has been revealed that an increase in students' verbal-linguistic intelligence is an increase in the medium criteria. To test whether the difference in increase is significant or not, an average difference test is performed with the Mann Whitney U Test. 
Recapitulation of the test results of the average difference in the increase in students' verbal-linguistic intelligence based on learning can be seen in Table 3.

TABLE 3. Test difference in average improvement of students verbal-linguistic intelligence

\begin{tabular}{ccccc}
\hline Learning & Mann-Whitney U & $\boldsymbol{Z}$ & $\boldsymbol{p}$-value (sig.1-tailed) & Information \\
\hline Scientific \& IG & 70.000 & -5.115 & 0.000 & $H_{0}$ is rejected \\
\hline
\end{tabular}

Based on the calculation results in Table 3, it can be seen that for the average increase in verbal-linguistic intelligence $p$-value (sig.1-tailed) is 0.000 less than 0.05 then $H_{0}$ is rejected. This means that the increase in students' verbal-linguistic intelligence is significantly better after being given a scientific approach assisted by Instagram.

\section{Descriptive Analysis of Kinesthetic-Body Intelligence}

Recapitulation of the initial and final score results of bodily-kinesthetic intelligence and normalized Gain based on learning can be seen in Table 4.

TABLE 4. Recapitulation of kinesthetic-body-intelligence enhancement

\begin{tabular}{|c|c|c|c|c|c|c|}
\hline \multirow{2}{*}{ Score } & \multirow{2}{*}{ Learning } & \multicolumn{2}{|c|}{ Score } & \multirow{2}{*}{$\bar{x}$} & \multirow{2}{*}{$S d$} & \multirow{2}{*}{$N$-Gain } \\
\hline & & Min & Max & & & \\
\hline $\begin{array}{c}\text { Pre-KBI } \\
\text { Akhir-KBI }\end{array}$ & Scientific \& IG & $\begin{array}{l}12 \\
13\end{array}$ & $\begin{array}{l}16 \\
21\end{array}$ & $\begin{array}{l}13,56 \\
17,19\end{array}$ & $\begin{array}{l}1,09 \\
2,30\end{array}$ & 0,56 \\
\hline
\end{tabular}

Based on Table 4 it appears that the kinesthetic-body intelligence of students with given learning with Scientific with IG is increasing. Although the qualifications for upgrading are in the medium criteria. The following are the complete enhancements to the following Figure 2.

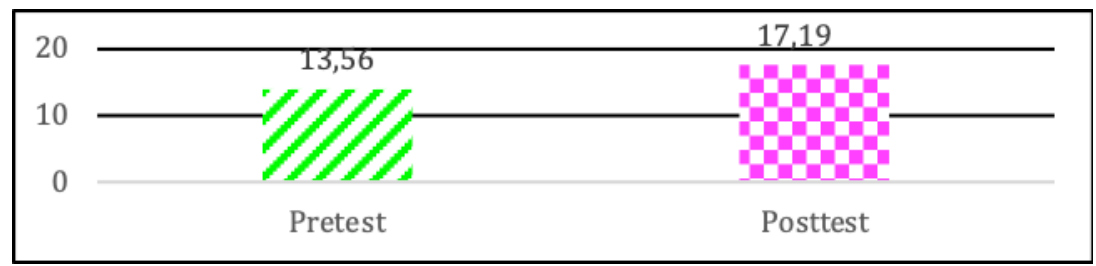

FIGURE 2. Average kinesthetic-body intelligence enhancement

\section{Inferential Analysis of Kinesthetic-Body Intelligence}

Descriptively revealed that the increase in kinesthetic-bodily intelligence students was an increase in the medium criteria. To test whether the difference in increase is significant or not, an average difference test was performed with the Mann Whitney U Test. Recapitulation of the test results of the average difference in the increase in kinestheticbody intelligence of students based on learning can be seen in the following Table 5.

TABLE 5. Test the difference in average of kinesthetic-body student improvement

\begin{tabular}{ccccc}
\hline Learning & Mann-Whitney U & $\boldsymbol{Z}$ & $\boldsymbol{p}$-value (sig.1-tailed) & Information \\
\hline Scientific \& IG & 55.000 & -5.425 & 0.000 & $H_{0}$ is rejected \\
\hline
\end{tabular}

Based on the calculation results in Table 5, it can be seen that for the average increase in kinesthetic-body intelligence $p$-value (sig.1-tailed) is 0.000 less than 0.05 then 
$H_{0}$ is rejected. This means that the increase in students' kinesthetic-bodily intelligence is significantly better after being given a scientific approach assisted by Instagram.

\section{DISCUSSION}

The research findings show that a scientific approach can improve student learning activities, creativity, and communication that can be seen in their Instagram posts. This can be seen in the process where students tell and practice their hobbies and post them on Instagram. In line with these results, several studies say a scientific approach can improve students' communication skills (Fadhilaturrahmi, 2017). It was also found that the application of a scientific approach could develop the creativity of early childhood as a whole (Pora, Sholeh, \& Anggraini, 2019). Besides, social media can also raise awareness about independence, self-esteem, and creativity (Supratman, 2018). Social media in learning uses Instagram. The study says Instagram has several important tools that are useful for educational purposes related to linguistic intelligence (Wiktor, 2012).

Students 'verbal-linguistic intelligence is developed by applying a scientific approach to the theme of students' hobbies then students are allowed to publish activities related to their hobbies such as biking, swimming, running, racing cars, and so on. The teacher observes how students tell their hobbies in Indonesian, Sundanese, or English. Students' language skills will be seen in the process of telling their hobbies accompanied by their father and mother or friend. (Wijaya, 2018). In line with this, the development of verbal-linguistic intelligence can be done in the scope of the family, school, and community. Students are given the freedom to express creatively their hobbies and publish them on Instagram. Besides verbal-linguistic intelligence can be divided into four learning preferences including mastery (knowing), interpersonal (social skills), understanding (discovery and reasoning), and self-expression (creativity). If student learning styles are adapted to appropriate teaching strategies, students' experience, performance, and learning achievement are very likely to improve (Strong, Silver, \& Perini, 2001). Linguistic intelligence can be enhanced in young children with activities that like to express themselves through language, like to read stories or to read and use language to help their understanding of the world about them (Lowenthal, 1997). The following are some activities on developing verbal-linguistic intelligence of learning using Instagram recorded in the image below.
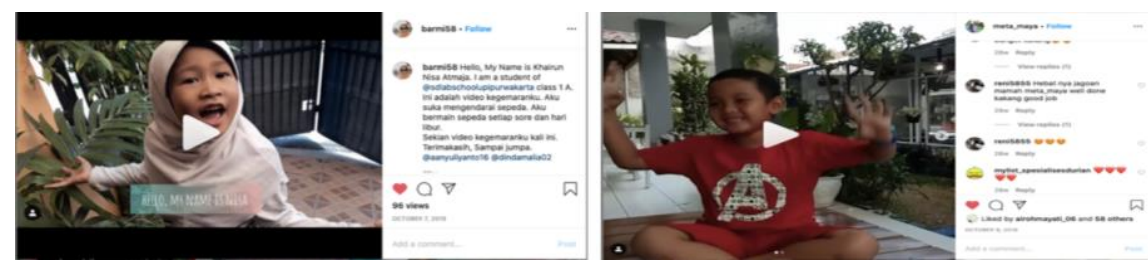

FIGURE 3. My hobby learning activities via instagram

Videos uploaded on Instagram by the accounts @barmi58 and @meta_maya show the expressions of students explaining their hobbies of cycling, swimming, and playing football. The student looks excited. In line with that user experience to obtain selfsatisfaction through Instagram can be explored even deeper through the process of receiving stimulus until the onset of human behavior (Zein \& Rachim, 2018). Also, students' verbal-linguistic intelligence looks very good with a complete explanation by introducing themselves and using three languages at once, namely Ind onesian, Sundanese, and English. The study says through Instagram students can practice 4 skills in English at once (Sesriyani \& Sukmawati, 2019). A study also said Instagram can be an effective pedagogical tool in second language acquisition if used and monitored appropriately (Shazali, Shamsudin, \& Yunus, 2019). Instagram can contribute to the students' confidence to speak in a foreign language and speaking skills (Rahmah, 2018). 
A study said that there was a significant difference in the kinesthetic intelligence of children aged 5-6 years between the experimental class TK Sejahtera 4 and the control class TK Negeri Pembina Kota Tasikmalaya. Namely, the increase in kinesthetic intelligence of children aged 5-6 years in the experimental class TK Sejahtera 4 is higher than the increase in kinesthetic intelligence of children aged 5-6 years in the control class of TK Negeri Pembina Kota Tasikmalaya with a 95\% confidence level (Respati, Nur, \& Rahman, 2018). The kinesthetic intelligence of students is seen in the activities of students' body movements in expressing their hobbies such as running, swimming, cycling, playing soccer, etc. posted on their Instagram. With these activities, their movement skills will be honed and developed. In line with this, bodily-kinesthetic intelligence can be improved in children by enjoying sports, movement, dancing, and working on projects directly. Some ways to maintain this intelligence are to involve children in sports, dancing, playing outdoors, and manipulative creative use (Lowenthal, 1997). The scientific approach through the stages of trying to allowing interacting with their environment. This is related to kinesthetic intelligence can be stimulated by physical interactions with the environment. When used in teaching, students who manipulate material can develop a greater understanding of skills (McKenzie, 2002). Here are some kinesthetic-body intelligence development activities using Instagram recorded in the image below.
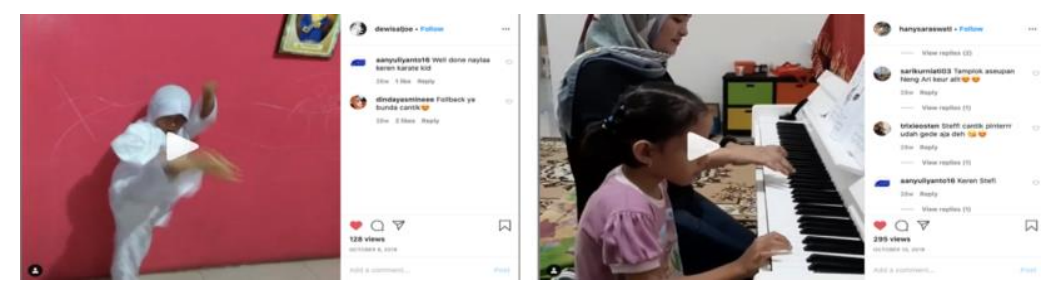

FIGURE 4. My hobby learning activities through instagram

The video uploaded by @dewisaljoe and @hanysaraswati shows students can develop and explore their kinesthetic through karate hobbies and the play piano well and happily. Instagram is considered to influence an effort to improve students' kinesthetic intelligence. The use of Instagram as a forum for students to develop their intelligence makes it easier for teachers in the assessment process too, because teachers can access videos of student learning outcomes. In line with that through Instagram, a person can get an assessment from others about himself because of posting photos and videos uploaded, so that many Instagram users tend to deliberately organize themselves to get an assessment from others (Pratiwi \& Janu, 2018). Also, the results of the research are generally in line with a study that says there is an increase in students' multiple intelligences after learning with a scientific approach to thematic learning as seen from the results of the analysis of the N-gain test which increased by 0.41 in the moderate category. (Dewi \& Rukmini, 2019). Based on the description Instagram assisted learning which is learning that applies technology has a positive impact and is considered effective. In line with that technology in learning is a strategy in conducting the learning process to be more effective by using technology (Yuliyanto, Fadriyah, Yeli, \& Wulandari, 2018). The use of Instagram is part of the use of e-learning which aims to improve the quality of students. Besides, the use of e-learning will change the paradigm that was originally using conventional media towards information technology-based learning media. Thus, learning activities will be more effective, efficient, and increase student creativity through the use of e-learning based media (Majid, Ridwan, Fauzi, \& Hikmawan, 2019). 


\section{CONCLUSION}

Based on the planned research objectives it was found that the Instagram-assisted scientific approach showed an increase in verbal-linguistic and kinesthetic-body intelligence low-grade students are in the criteria and inferentially verbal-linguistic intelligence and kinesthetic-body intelligence low-grade students are better than before being given learning with an Instagram-assisted scientific approach. The scientific approach provides an opportunity for students to develop verbal-linguistic intelligence through the stages of observing and communicating. The kinesthetic-body intelligence of students develops through the stage of trying to express their hobbies. Instagram can facilitate and make students excited about exploring student intelligence and make it easier for teachers to make assessments. It is fitting that the development of learning can facilitate the diversity of student intelligence by utilizing social media that are developing at this time to facilitate the learning and assessment process.

\section{REFERENCES}

1. Ariani, Y., Johar, R., \& Marwan, M. (2019). Penggunaan Software Cabri 3D untuk Meningkatkan Kemampuan Spasial Siswa Sekolah Menengah Pertama. Jurnal Peluang, $7(2), 11-21$.

2. Armstrong, T. (2009). Multiple Intelligences in The Classroom. Virginia: ASCD.

3. Basith, A., \& Syafi'i, A. (2019). Instagram as Media in Teaching Writing Recount Text for Senior High School Students. SALEE: Study of Applied Linguistics and English Education, 1(1), 11-20.

4. Bustamam, R., Trinova, Z., \& Febrianto. (2016). Implementasi Strategi Multiple Intelligences Pada Pembelajaran Pendidikan Agama Islam Di SDIT Mutiara Hati Payakumbuh. Jurnal Tarbiyah Al-Awlad, 6(2), 625-634.

5. Dewi, R. A., \& Rukmini, P. (2019). The effect of thematic learning by using a scientific approach to increase the multiple intelligence of students. Jurnal Prima Edukasia, $7(1), 40-46$.

6. Fadhilaturrahmi. (2017). Penerapan Pendekatan Saintifik untuk Meningkatkan Kemampuan Komunikasi Matematik Peserta Didik di Sekolah Dasar. EduHumaniora: Jurnal Pendidikan Dasar, 9(2), 109-118.

7. Gardner, H. (1993). Multiple Intelligence. New York: Basic Book.

8. Gay, L. R., Milss, G. E., \& Airasian, P. (2012). Educational Research Competencies for Analysis and Applications. Boston: Pearson Education.

9. Hanifah, T. U. (2014). Pemanfaatan Media Pop-Up Book Berbasis Tematik Untuk Meningkatkan Kecerdasan Verbal-Linguistik Anak Usia 4-5 Tahun (Studi Eksperimen Di TK Negeri Pembina Bulu Temanggung). Belia: Early Childhood Education Papers, $3(2), 46-54$.

10. Hanoum, R. N. (2014). Mengembangkan Keterampilan Berpikir Tingkat Tinggi Mahasiswa Melalui Media Sosial. Edutech, 1(3), 400-408.

11. Hasanah, I. (2016). Developing English Materials for Character Building Based on 2013 Curriculum for Eighth Grade Student. Indonesian Journal of Language Teaching and Linguistics, 1(2), 111-126.

12. Katni. (2015). Strategi Pembelajaran Pendidikan Agama Islam dengan Penerapan Metode Pembelajaran Berbasisi Multiple Intelligences. Tarbawi, 1(2), 27-40.

13. Kim, K. (2019). Role and Perspective of Sport Science in Health Promotion and Elite Sport. The Asian Journal of Kinesiology, 21(2), 31-39.

14. Kusrini, E., \& Rizkianto, I. (2017). Developing Mathematics Learning Materials based on Multiple Intelligence Theory, Learning Trajectory, and Conceptual Knowledge in the Topic of Probability for Eighth Graders. University of Muhammadiyah Malang's 1st International Conference of Mathematics Education (INCOMED 2017). 160, pp. 302309. Malang: Atlantis Press. 
15. Laduni, I. S., Novianti, R., \& Febrialismanto. (2016). Pengaruh Permainan Berburu Ember Harta Karun terhadap Kecerdasan Kinestetik Anak Usia 4-5 Tahun di Paud Asshifa Citra Kecamatan Tampan Kota Pekanbaru. Jurnal Online Mahasiswa Fakultas Keguruan dan Ilmu Pendidikan Universitas Riau, 3(2), 1-12.

16. Lowenthal, B. (1997). Useful Early Childhood Assessment: Play-Based, Interviews and Multiple Intelligences. Early Child Development and Care, 129(1), 43-49.

17. Machin, A. (2014). Implementasi Pendekatan Saintifik, Penanaman Karakter, dan Konservasi pada Pembelajaran Materi Pertumbuhan. Jurnal Pendidikan IPA Indonesia, 3(1), 28-35.

18. Majid, N. W., Ridwan, T., Fauzi, A., \& Hikmawan, R. (2019). Integrating of E-learning to Improve Students Competence in Vocational School. 5th UPI International Conference on Technical and Vocational Education and Training (ICTVET 2018). 299, pp. 73-79. Bandung: Atlantis Press.

19. McKenzie, W. (2002). Media Selection: Mapping Technologies to Intelligences. Virginia Society for Technology in Education, 17(1), 6-13.

20. Meltzer, D. E. (2002). The relationship between mathematics preparation and conceptual learning gains in physics: A possible "hidden variable" in diagnostic pretest scores. American Association of Physics Teachers, 70(12), 1259-1268. doi:10.1119/1.1514215

21. Narpila, S. D. (2016). Peningkatan Kemampuan Spasial dan Self Efficacy Siswa melalui Pembelajaran Inquiry Berbantuan Software Cabri 3D di Kelas X SMA YPK Medan. Jurnal Tarbiyah, 23(1), 150-173.

22. Nining. (2018). Penerapan Model Kooperatif Tipe Think-Pair-Share untuk Meningkatkan Kecerdasan Linguistik Siswa Sekolah Dasar. JMIE: Journal of Madrasah Ibtidaiyah Education, 2(2), 245-253.

23. Patton, M. Q. (2015). Qualitative research and evaluation methods. Thousand Oaks, CA: SAGE.

24. Pora, K., Sholeh, A., \& Anggraini, H. (2019). Penerapan Pendekatan Saintifik Dalam Pengembangan Kreativitas Anak Usia Dini Kelompok B Tk Model, Kota Malang. Prosiding Seminar Nasional Pendidikan dan Pembelajaran Bagi Guru dan Dosen. 3, pp. 988-995. Malang: Universitas Kanjuruhan Malang.

25. Pratiwi, F., \& Janu, L. (2018). Instagram Di Kalangan Mahasiswa FIB UHO. Etnoreflika, $7(3), 222-229$.

26. Purwaningsih, E. (2014). Penggunaan Metode Bermain dengan Teknik Leader Conference dalam Upaya Menigkatkan KecerdasanLinguistik Anak Usia Dini di Taman Kanak-kanak Cendekia Leadership School Kecamatan Cimenyan Kabupaten Bandung. Jurnal Empowerment, 4(1), 106-119.

27. Putri, S. N., Yuwono, J., \& Utami, Y. T. (2018). Peningkatan Kecerdasan Kinestetik Melalui Pembelajaran Tari Kreasi Nyi Pohaci Sanghyang Sri (Penelitian Tindakan Anak Tunarungu Kelas X SMALB Di SKh Negeri 02 Lebak). Jurnal UNIK Pendidikan Luar Sekolah, 3(2).

28. R, E. R., \& Seftika, S. (2019). How is Instagram Implemented in Teaching Speaking? Eleventh Conference on Applied Linguistics (CONAPLIN 2018). 254, pp. 386-388. Bandung: Atlantis Press.

29. Rahmah, R. E. (2018). Sharing Photographs on Instagram Boosts Students' SelfConfidence in Speaking English. Pedagogy Journal of English Language Teaching, 6(2), 148-158.

30. Respati, R., Nur, L., \& Rahman, T. (2018). Gerak dan Lagu Sebagai Model Stimulasi Pengembangan Kecerdasan Kinestetik Anak Usia Dini. Jurnal Pendidikan Usia Dini, 12(2), 321-330.

31. Riana, N., Monawati, \& Hasan, B. (2017). Hubungan Antara Kecerdasan Linguistik dengan Kecerdasan Logis Matematis Siswa Kelas V SD Negeri Lamreung Aceh Besar. Jurnal Ilmiah Pendidikan Guru Sekolah Dasar, 2(3), 15-23. 
32. Roberts, T. M. (2010). The experience of dance class: Exploring multiple intelligences instruction on student academic stress. Dissertation: Capella University.

33. Rubiyati, Asrori, M., \& Wicaksono, L. (2018). Pengaruh Pemanfaatan Media Sosial Instagram Terhadap Kreativitas Belajar Pada Remaja Kelas VII. Jurnal Pendidikan dan Pembelajaran Khatulistiwa, 7(5), 1-8.

34. Rusnah, \& Mulya, O. T. (2018). Meningkatkan Keterampilan Berpikir Kritis Siswa Melalui Pendekatan Saintifik Di Sekolah Dasar. Jurnal Gentala Pendidikan Dasar, 3(2), 239-256.

35. Sesriyani, L., \& Sukmawati, N. N. (2019). Analisis Penggunaan Instagram Sebagai Media Pembelajaran Bahasa Inggris Pada Program Studi Pendidikan Ekonomi. EDUKA : Jurnal Pendidikan, Hukum, dan Bisnis, 4(1), 9-15.

36. Setyorini, R., Saddhono, K., Ermanto, Wildan, M., \& Kirom, S. (2019). The Effort of Implementing of The Big Book as A Media to Improve The Intelligence of Linguistic Verbals for Early Childhood. Journal of Physics: Conference Series, 1339(012087).

37. Shazali, S. S., Shamsudin, Z. H., \& Yunus, M. M. (2019). Instagram: A Platform to Develop Student's Writing Ability. International Journal of Academic Research in Business and Social Sciences, 9(1), 89-98.

38. Strong, R., Silver, H., \& Perini, M. (2001). Teaching what matters most: Standards and strategies for raising student achievement. Virginia: Association for Supervision and Curriculum Development.

39. Supratman, L. P. (2018). Penggunaan Media Sosial oleh Digital Native. Jurnal Ilmu Komunikasi, 15(1), 47-60.

40. Syahputra, E. (2013). Peningkatan Kemampuan Spasial Siswa melalui Penerapan Pembelajaran Matematika Realistik. Cakrawala Pendidikan, 32(3), 353-364.

41. Tonra, W. S., \& Salim, A. (2018). Pengembangan Lembar Kegiatan Mahasiswa (LKM) Kalkulus Berbantuan Software Geogebra untuk Meningkatkan Kemampuan Spasial. Jurnal Saintifik, 4(2), 156-166.

42. Totikova, G., Aldabergenov, N., Salmirza, J., Nazarova, G., Gurbanova, A., Madiyarov, N., \& Yessaliyev, A. (2019). Criteria-based Assessment of Spatial Representations in Primary School Students. Elementary Education Online, 18(2), 461-471.

43. Tunc, M. P., Cakriloglu, E., \& Bulut, S. (2020). Exploring self-efficacy beliefs within the context of teaching mathematics with concrete models. Elementary Education Online, 19(1), 100-117.

44. UU No 20 Tahun 2003. (2003). Sistem Pendidikan Nasional. Jakarta: Lembaran Negara Republik Indonesia Tahun 2003 Nomor 4301.

45. Wakhidah, N. (2018). Pembelajaran dengan pendekatan saintifik terhadap kemampuan berpikir kritis mahasiswa calon guru madrasah ibtidaiyah. Premiere Educandum: Jurnal Pendidikan Dasar dan Pembelajaran, 8(1), 150-160.

46. Wijaya, I. K. (2018). Developing The Verbal-Linguistic Intelligence Of Elementary School Students In The Scope Of Family, School, And Community. Yavana Bhāshā: Journal of English Language Education, 1(2), 64-68.

47. Wiktor, K. (2012). A Billion Dollar Idea: Instagram and Language Learning. Retrieved from Brave Learning: https://bravelearning.com/2012/04/20/a-billion-dollar-ideainstagram- and-language-learning/

48. Yolcu, B., \& Kurtulus, A. (2010). A study on Developing Sixth-Grade Students' Spatial Visualization Ability. Elementary Education Online, 9(1), 256-274.

49. Yuliyanto, A., Fadriyah, A., Yeli, K. P., \& Wulandari, H. (2018). Pendekatan Saintifik untuk Mengembangkan Karakter Disiplin dan Tanggung Jawab Siswa SD. Metodik Didaktik, 13(2), 87-98.

50. Yuliyanto, A., Fadriyah, A., Yeli, K. P., \& Wulandari, H. (2018). Teknologi Pembelajaran untuk Mengembangkan Karakter Disiplin dan Tanggung Jawab Siswa Sekolah Dasar melalui Pendekatan Saintifik. Prosiding Seminar Nasional 2017 Menjadi Orang Tua Cerdas Di Era Digital (pp. 58-67). Purwakarta: Program Studi Pendidikan Guru Pendidikan Anak Usia Dini Universitas Pendidikan Indonesia Kampus Purwakarta . 
51. Yustitia, V., Rusminati, S. H., \& Sulistyawati, I. (2018). Implementasi lesson study menggunakan model think pair share dan pendekatan saintifik. Premiere Educandum: Jurnal Pendidikan Dasar dan Pembelajaran, 8(1), 88-97.

52. Zein, A. O., \& Rachim, A. A. (2018). Tinjauan Cafe Instagramable pada One Eighty Coffee Bandung. ATRAT: Jurnal Seni Rupa, 6(3), 286-293.

\section{PROFILE}

Aan Yuliyanto is a Masters Student in Primary Education Study Program at the School of Postgraduate Studies Universitas Pendidikan Indonesia. He also became an elementary school teacher at UPI Laboratory Elementary School in Purwakarta Campus from July 2018 to January 2020. Also, he is active in research projects in the fields of mathematical self-efficacy, and multiple intelligences in elementary schools.

Dinda Mifta Amalia is an elementary school teacher at the UPI Campus Laboratory Primary School in Purwakarta from September 2019 until now.

Idat Muqodas is a Lecturer in the Education Study Program for Early Childhood Teacher Education at the UPI Campus in Purwakarta. He is also a reviewer of the Al Ibtida: Jurnal Pendidikan Guru MI at IAIN Cirebon and Metodik Didaktik: Jurnal Pendidikan Ke-SD-An elementary education study program UPI Campus in Purwakarta. Also, he is active in research projects in the field of guidance and counseling. 